\title{
IPTEK BAGI KELOMPOK LANSIA DENGAN RELAKSASI BENSON
}

\author{
Science And Technology For The Elderly Group With Benson Relaxation
}

\author{
Rodiyah, Pepin Nahariani, Shanti Rosmaharani \\ STIKES PEMKAB JOMBANG \\ Email : ners_ody@yahoo.com
}

\begin{abstract}
ABSTRAK
Fenomena lansia di masyarakat mengeluh sering merasakan sakit pada persendian, sakit untuk berjalan, untuk pindah posisi dari duduk ke berdiri sehingga aktivitas terganggu Tekhnik relaksasi benson adalah relaksasi ini merupakan gabungan antara relaksasi dengan keyakinan agama yang dianut. Respon relaksasi yang melibatkan keyakinan yang dianut mempercepat keadaan menjadi relaks. Teknik relaksasi benson tersebut akan mempengaruhi sistem saraf simpatis dan para simpatis sehingga menyebabkan otot-otot menjadi rileks dan nyeri akan berkurang.

Tujuan dari kegiatan ini membantu para lansia untuk mengatasi permasalahan yang selama ini dialami oleh lansia dan sebagai alternative prngobstsn non farmakologi untuk lansia yang tinggal dipanti

Hasil dari kegiatan ini adalah praktek bersama relaksasi benson dengan lansia dan di sarankan lansia menggunakannya secara mandiri ketika mengalami masalah.
\end{abstract}

Kata Kunci: Lansia, Relaksasi Benson

\section{PENDAHULUAN}

Proses menua merupakan proses alami kehidupan dan tidak bisa di hindari setiap individu. Perubahan usia akan menimbulkan pada struktur dan fisiologis dari berbagai organ dan sistem yang ada dalam tubuh manusia.

Nyeri bukan masalah dari penuaan tapi sering menjadi masalah bagi lansia, lansia di komunitas $50 \%$ pernah mengalami masalah nyeri.

Tekhink relaksasi benson untuk mengurangi gangguan insomnia, mengurangi kecemasan atau untuk membuat tubuh istirahat sejenak. Teknik relaksasi benson tersebut akan mempengaruhi sistem saraf simpatis dan para simpatis sehingga menyebabkan otot-otot menjadi rileks dan nyeri akan berkurang. Fenomena lansia di masyarakat mengeluh sering merasakan sakit pada persendian, sakit untuk berjalan, untuk pindah posisi dari duduk ke berdiri sehingga aktivitas terganggu.

Hasil penelitian Peter Pressman (Benson, 2000) menunjukkan tiga puluh wanita lanjut usia yang sembuh dari koreksi bedah pada tulang punggung yang patah, diteliti untuk menemukan hubungan antara keyakinan religius mereka dengan kesehatan medis dan psikiatrik. Pasien dengan keimanan yang kuat mampu untuk berjalan lebih jauh secara bermakna dan lebih kecil kemungkinannya untuk mengalami depresi. Pada penelitian Gunawan (2013), tekhnik relaksasi benson menunjukkan pengurangan nyeri sendi. Tekhnik relaksasi benson adalah relaksasi ini merupakan gabungan antara relaksasi dengan keyakinan agama yang dianut. Respon relaksasi yang melibatkan keyakinan yang dianut mempercepat keadaan menjadi relaks (kombinasi respon relaksasi dengan keyakinan) (Benson, 2000, dalam Purwanto, 2009).

\section{METODE PELAKSANAAN}

Kegiatan pengabdian masyarakat tentang di lakukan tanggal 28 Februari 2018 dalam Kegiatan relaksasi benson ini dilakukan guna membantu para lansia untuk mengatasi masalah- masalah yang mereka alami seperti stress, kecemasan, insomnia,nyeri dll dengan mengabungkan keyakinan mereka.

Kegiatan ini dilakukan dengan cara

1. Lansia berkumpul di ruang auditorium PSTW

2. Lansia mengisi daftar hadir

3. Perkenlaan antara pelaksana dengan lansia 
Kegiatan inti:

1. Penyuluhan tentang relaksasi benson

2. Mengajari tentang relaksasi benson

3. Praktek bersama tentang relaksasi benson

4. Beberapa lansia diminta untuk mempraktekkan ke depan tapi mereka tidak mau dikarenakan beberapa alasan diantaranya kerena nyeri

Kegiatan penutup.

1. Mengulang kembali bagaimana tehnik relaksasi benson

2. Menyarankan untuk mengerjakan relaksasi benson ini ketika mereka kembali ke wisma dan dikerjakan minimal 2 kali sehari

\section{HASIL DAN PEMBAHASAN}

Kegiatan pengabdian masyarakat ini dilaksanakan di PSTW Jombang tanggal 28 Februari 2018 mulai pulul 10 s/d 12yang dikuti oleh lansia yang ada di PSTW. Kegiatan diawali dengan pembukaan yang diisi oleh kepala seksi pelayanan dan pembinaaan lanjut usia Nenti Sajarwanti .

Sasaran kegiatan pengabdian masyarakat adalah lansia yang ada di PSTW jombang yang menderita stress cemas, insomnia, nyeri dll.

Berdasarkan hasil penelitian Purwanto (2009), tekhink relaksasi benson untuk mengurangi gangguan insomnia, mengurangi kecemasan atau untuk membuat tubuh istirahat sejenak. Hasil penelitian Peter Pressman (Benson, 2000) menunjukkan tiga puluh wanita lanjut usia yang sembuh dari koreksi bedah pada tulang punggung yang patah, diteliti untuk menemukan hubungan antara keyakinan religius mereka dengan kesehatan medis dan psikiatrik. Pasien dengan keimanan yang kuat mampu untuk berjalan lebih jauh secara bermakna dan lebih kecil kemungkinannya untuk mengalami depresi.

Para lansia sangat antusias dengan kegiatan ini terbukti banyak beberapa lansia yang bertanya tetntang keluhan mereka.

Selanjutnya mereka disarankan untuk mencoba tehnik relaksasi ini di kamar masing -masing 2 kali sehari.

\section{KESIMPULAN}

1. Relaksasi benson perlu diterapkan pada lansia untuk mengatasi masalah lansia

2. Relaksasi ini mengabungkan antara relaksasi dengan keyakinan lansia.

3. Relaksasi ini bias dilakukan secara mandiri maupun dengan bimbingan.

Saran untuk pengabdian masyarakat ini adalah diperlukan dukungan dari pihak panti untuk mengagendakan adanya relaksasi benson ini bersama - sama .

\section{DAFTAR PUSTAKA}

Asmadi. 2008. Konsep dan Aplikasi Kebutuhan Dasar Klien. Jakarta : Salemba Medika.

Suharsimi.2006. Prosedur Penelitian. Suatu pendekatan Praktik. Jakarta: PT. Rineka Cipta.

Benson, Herbert. 2006. Trancesolutionstde relaxation response .www.trancesolutions.com

Maryam, S., Ekasari, M., Rosidawati, Jubaedi, A., \& Batubara. 2008. MengenalUsia Lanjut dan perawatanya. Jakarta: Salemba Medika.

Nugroho,H.Wahjudi.2008.Keperawatan Gerontik Geriatri. Jakarta: EGC

Stanley, Mickey. 2006. Buku Ajar Keperawatan Gerontik. Edisi 2. Jakarta: EGC.

Purwanto, Setyo. 2009. Relaksasi Dzikir Pengaplikasian dari Benson.http://Fakultas Psikologi Muhammadiyah Surakarta 